\title{
IMPLEMENTASI SERTIFIKASI DOSEN
}

\author{
Irwan Saleh Dalimunthe \\ Fakultas Tarbiyah dan IImu Keguruan IAIN Padangsidimpuan \\ Jalan T. Rizal Nurdin KM. 4,5 Sihitang Padangsidimpuan \\ E-mail: irwansaleh_dlmt@yahoo.co.id
}

\begin{abstract}
Abstrak
Selain kualifikasi akademik, dosen harus memiliki 4 (empat) kompetensi, yaitu kompetensi professional, kompetensi pedagogik, kompetensi kepribadian, dan kompetensi social, dengan bukti memperoleh sertifikat pendidik. Pelaksanaan sertifikasi dosen yang telah berlangsung beberapa tahun secara umum telah berjalan secara efektif dan dapat meningkatkan kinerja dosen. Hal ini dapat dilihat dari peningkatan jumlah penulisan ilmiah dan buletin, namun dalam bidang pendidikan dan pengajaran masih terdapat dosen yang belum maksimal melaksanakan proses perkuliahan. Hambatan yang dihadapi antara lain masih rendahnya pemahaman sebagian dosen terhadap tugas dan beban kerja yang harus dilaksanakannya, dan sebagian dosen masih rendah tingkat kesadaran untuk melaksanakan tugas Tridharma Perguruan Tingginya.
\end{abstract}

\begin{abstract}
In addition to academic qualifications, lecturess must have 4 (four) competencies: professional competence, pedagogical competence, personal competence and social competence by having teacher certificate. Lecturer certification implementation that has lasted several years in general have been effective and can improve the performance of lecturers. It can be seen from the increasing number of scientific writing and bulletins, but in the field of education and teaching there are lecturers who have not been up to implement the lecture. Barriers faced by, among others, is the lack of understanding most of the lecturers of the task and the workload that must be implemented, and some professors still low level of awareness of Tridharma Perguruan Tinggi.
\end{abstract}

\section{Kata Kunci: Sertifikasi, Beban Kerja Dosen, Kinerja}




\section{Pendahuluan}

Dinamika perkembangan masyarakat melaju sangat pesat seiring dengan kemajuan ilmu pengetahuan dan teknologi. Hal ini menuntut semua pihak untuk beradaptasi terhadap perubahan yang terjadi di dalam masyarakat. Kemajuan ilmu pengetahuan dan teknologi telah memunculkan paradigma baru dalam masyarakat, bahwa bukan Sumber Daya Alam (SDA) melimpah yang dominan mengantarkan suatu bangsa menuju pada kemakmuran, tetapi ketangguhan daya saing Sumber Daya Manusia (SDM), keunggulan ilmu pengetahuan, dan penguasaan teknologi bangsa tersebutlah yang sangat berperan untuk mencapai kemakmuran dan kesejahteraan. Bahkan SDM yang menguasai ilmu pengetahuan dan teknologi cenderung memanfaatkan teknologinya untuk menguasai SDA bangsa lain.

Undang-Undang Dasar Negara Republik Indonesia Tahun 1945 mengamanatkan bahwa setiap warga negara berhak mendapat pendidikan. Pemerintah mengusahakan dan menyelenggarakan satu sistem pendidikan nasional, yang meningkatkan keimanan dan ketakwaan serta akhlak mulia dalam rangka mencerdaskan kehidupan bangsa. Pemerintah memajukan ilmu pengetahuan dan teknologi dengan menjunjung tinggi nilai-nilai agama dan persatuan bangsa untuk kemajuan peradaban serta kesejahteraan umat manusia. ${ }^{1}$

Tantangan persaingan yang semakin tajam pada era globalisasi menuntut peningkatan kualitas profesional dan efisiensi secara terus menerus, sehingga kemampuan daya saing professional bisa lebih kompetitif. Era globalisasi mengubah hakekat kerja dari amatiran menuju kepada profesionalisasi di segala bidang dan aspek kehidupan, termasuk profesi di bidang pendidikan. Oleh karena itu, sebagai amanat undangundang, kualitas profesionalisme selalu diupayakan, baik melalui ketentuan kualifikasi pendidikannya maupun kegiatan pelatihan dalam berbagai bentuknya, seperti pendidikan dan latihan (diklat), penataran dan pelibatan

1 Undang-Undang Dasar Negara Republik Indonesia Tahun 1945, Pasal 31, Ayat 1, 3 , dan 5 . 
dalam berbagai seminar untuk meng-update wawasannya dalam kompetensi pedagogik dan akademik.

Meskipun pemerintah telah menerapkan program sertifikasi dosen dalam beberapa tahun terakhir, namun capaian tujuannya belu maksimal, masih terdapat fenomena bahwa, profesionalisme dosen masih dipandang belum memuaskan. Dosen-dosen yang sudah mempunyai sertifikat pendidik belum menampilkan kinerja profesional secara optimal, sehingga masih menimbulkan pertanyaan tentang efektifitas dan efisiensi penerapan program tersebut. Berdasarkan hal di atas, tulisan itu mencoba mengetahui dan memahami lebih lanjut efektifitas pelaksanaan sertifikasi tersebut.

\section{Dosen Sebagai Tenaga Profesional}

Sebagai penjabaran amanat Undang-Undang Dasar 1945, Pemerintah RI kemudian mengeluarkan Undang-undang Nomor 20 Tahun 2003 tentang Sistem Pendidikan Nasional, yang memiliki visi terwujudnya sistem pendidikan sebagai pranata sosial yang kuat dan berwibawa untuk memberdayakan semua warga negara Indonesia berkembang menjadi manusia yang berkualitas sehingga mampu dan proaktif menjawab tantangan zaman yang selalu berubah. Kualitas manusia yang dibutuhkan oleh bangsa Indonesia pada masa yang akan datang adalah yang mampu menghadapi persaingan yang semakin ketat dengan bangsa lain di dunia. Kualitas manusia Indonesia tersebut dihasilkan melalui penyelenggaraan pendidikan yang bermutu.

Oleh karena itu, dosen, sebagaimana juga guru, mempunyai fungsi, peran, dan kedudukan yang sangat strategis. Pendidik merupakan tenaga profesional. Kedudukan dosen sebagai tenaga profesional mempunyai visi terwujudnya penyelenggaraan pembelajaran sesuai dengan prinsip-prinsip profesionalitas untuk memenuhi hak yang sama bagi setiap warga negara dalam memperoleh pendidikan yang bermutu. ${ }^{2}$

Undang-undang Nomor 20 Tahun 2003 kemudian diperkuat dengan penetapan Undang-undang Republik Indonesia Nomor 14 Tahun 2005

2 Undang-undang Nomor 20 Tahun 2003 tentang Sistem Pendidikan Nasional, Pasal 39, Ayat 2. 
tentang Guru dan Dosen. Undang-undang ini juga menjadi salah satu dasar kebijakan untuk memperkuat eksistensi sumber daya pendidikan sebagai tenaga profesional, seperti profesi-profesi lainnya. Undang-undang Nomor 14 Tahun 2005 tersebut mengamanatkan bahwa dosen sebagai pendidik profesional dan ilmuwan mempunyai tugas utama melaksanakan Tridharma Perguruan Tinggi, yaitu mentransformasikan, mengembangkan dan menyebarluaskan ilmu pengetahuan, teknologi dan seni melalui pendidikan, penelitian dan pengabdian kepada masyarakat. ${ }^{3}$

Pengakuan kedudukan dosen, dan juga guru, sebagai tenaga profesional mempunyai misi untuk melaksanakan tujuan Undang-Undang ini sebagai berikut: mengangkat martabat, menjamin hak dan kewajiban, meningkatkan kompetensi, memajukan profesi serta karier, meningkatkan mutu pembelajaran, mningkatkan mutu pendidikan nasional, mengurangi kesenjangan ketersediaan dosen antar daerah dari segi jumlah, mutu, kualifikasi akademik, dan kompetensi; mengurangi kesenjangan mutu pendidikan antar daerah, dan meningkatkan pelayanan pendidikan yang bermutu.

Berdasarkan misi tersebut, kedudukan dosen sebagai tenaga profesional berfungsi untuk meningkatkan martabat dosen serta mengembangkan ilmu pengetahuan, teknologi, dan seni untuk meningkatkan mutu pendidikan nasional. Sejalan dengan fungsi tersebut, kedudukan dosen sebagai tenaga profesional bertujuan untuk melaksanakan sistem pendidikan nasional dan mewujudkan tujuan pendidikan nasional, yakni berkembangnya potensi peserta didik agar menjadi manusia yang beriman dan bertakwa kepada Tuhan Yang Maha Esa, berakhlak mulia, sehat, berilmu, cakap, kreatif, mandiri, serta menjadi warga negara yang demokratis dan bertanggung jawab.

Untuk meningkatkan penghargaan terhadap tugas dosen, kedudukan dosen pada jenjang pendidikan tinggi perlu dikukuhkan dengan pemberian sertifikat pendidik. Sertifikat tersebut merupakan pengakuan atas kedudukan dosen sebagai tenaga profesional. Dalam melaksanakan

3 Undang-undang Republik Indonesia Nomor 14 Tahun 2005 tentang Guru dan Dosen, Bab I, Pasal 1, Ayat 2 
tugasnya, dosen harus memperoleh penghasilan di atas kebutuhan hidup minimum sehingga memiliki kesempatan untuk meningkatkan kemampuan profesionalnya. Selain itu, perlu juga diperhatikan upaya-upaya memaksimalkan fungsi dan peran strategis dosen yang meliputi penegakan hak dan kewajiban dosen sebagai tenaga profesional, pembinaan dan pengembangan profesi guru dan dosen, perlindungan hukum, perlindungan profesi, serta perlindungan keselamatan dan kesehatan kerja.

Dalam pelaksanaannya tentu diperlukan strategi yang meliputi: penyelenggaraan sertifikasi pendidik berdasarkan kualifikasi akademik dan kompetensi; pemenuhan hak dan kewajiban dosen sebagai tenaga profesional yang sesuai dengan prinsip profesionalitas; penyelenggaraan kebijakan strategis dalam pengangkatan, penempatan, pemindahan, dan pemberhentian dosen sesuai dengan kebutuhan, baik jumlah, kualifikasi akademik, maupun kompetensi yang dilakukan secara merata, objektif, dan transparan untuk menjamin keberlangsungan pendidikan; penyelenggaraan kebijakan strategis dalam pembinaan dan pengembangan profesi dosen untuk meningkatkan profesionalitas dan pengabdian para guru dan dosen; peningkatan pemberian penghargaan dan jaminan perlindungan terhadap guru dan dosen dalam pelaksanaan tugas profesional; peningkatan peran organisasi profesi untuk menjaga dan meningkatkan kehormatan dan martabat dosen dalam pelaksanaan tugas sebagai tenaga profesional; penguatan kesetaraan antara dosen yang bertugas pada satuan pendidikan yang diselenggarakan oleh Pemerintah dengan dosen yang bertugas pada satuan pendidikan yang diselenggarakan oleh masyarakat; penguatan tanggung jawab dan kewajiban Pemerintah dalam merealisasikan pencapaian anggaran pendidikan untuk memenuhi hak dan kewajiban guru dan dosen sebagai tenaga profesional; dan peningkatan peran serta masyarakat dalam memenuhi hak dan kewajiban guru dan dosen. ${ }^{4}$

Oleh karena itu, sebagai amanat undang-undang, kualitas profesionalisme selalu diupayakan, baik melalui ketentuan kualifikasi

${ }^{4}$ Lihat Penjelasan atas Undang-undang Republik Indonesia Nomor 14 Tahun 2005 tentang Guru dan Dosen. 
pendidikannya maupun kegiatan pelatihan dalam berbagai bentuknya, seperti pendidikan dan latihan (diklat), penataran dan pelibatan dalam berbagai seminar untuk meng-update wawasannya dalam kompetensi pedagogik dan akademik. Meskipun pemerintah telah menerapkan program sertifikasi dosen dalam beberapa tahun terakhir, namun menurut pengamatan awal, peneliti melihat masih terdapat fenomena bahwa, profesionalisme dosen masih dipandang belum memuaskan. Dosen-dosen yang sudah mempunyai sertifikat pendidik belum menampilkan kinerja profesional secara optimal, sehingga masih menimbulkan pertanyaan tentang efektifitas dan efisiensi penerapan program tersebut.

\section{Kedudukan Dosen}

Dalam Undang-undang Republik Indonesia Nomor 14 Tahun 2005 tentang Guru dan Dosen, pasal 1, disebutkan bahwa dosen adalah pendidik profesional dan ilmuwan dengan tugas utama mentransformasikan, mengembangkan, dan menyebarluaskan ilmu pengetahuan, teknologi, dan seni melalui pendidikan, penelitian, dan penambian kepada masyarakat. Pemaknaan dosen dalam Undang-undang terakhir ini mengindikasikan bahwa dosen adalah pendidik dan juga ilmuwan. Tentu saja pengertian ini mewarnai fungsi, status, dan tugas dosen pada penjelasan berikutnya.

Lebih lanjut, dalam Undang-undang Nomor 14 tersebut, dalam pasal 6 dinyatakan bahwa kedudukan dosen adalah sebagai tenaga profesional bertujuan untuk melaksanakan sistem pendidikan nasional dan mewujudkan tujuan pendidikan nasional, yaitu berkembangnya potensi peserta didik agar menjadi manusia yang beriman dan bertakwa kepada Tuhan Yang Maha Esa, berakhlak mulia, sehat, berilmu, cakap, kreatif, mandiri, serta menjadi warga negara yang demokratis dan bertanggung jawab. Pencapaian tujuan pendidikan nasional ini merupakan tujuan pembelajaran yang dilaksanakan oleh dosen di IAIN Padangsidimpuan.

Dosen wajib memiliki kualifikasi akademik, kompetensi, sertifikat pendidik, sehat jasmani dan rohani, dan memenuhi kualifikasi lain yang dipersyaratkan satuan pendidikan tinggi tempat bertugas, serta memiliki 
kemampuan untuk mewujudkan tujuan pendidikan nasional. Tentu ini menghendaki adanya persyaratan bagi profesi dosen. Hal ini pula mengindikasikan adanya standar mutu yang harus dimiliki dan dicapai oleh dosen dalam melaksanakan profesinya.

Dalam Undang-undang tersebut juga dinyatakan bahwa kualifikasi akademik yang harus dipenuhi oleh dosen adalah lulusan program magister untuk program diploma atau program sarjana, dan lulusan program doktor untuk program pascasarjana. Kualifikasi akademik minimal strata 2 menjadi persyaratan profesi dosen umumnya, dan di IAIN Padangsidimpuan khususnya.

Selain kualifikasi akademik, dosen harus memiliki 4 (empat) kompetensi, yaitu kompetensi professional (keluasan wawasan akademik dan kedalaman keilmuan dalam bidang keilmuan yang ditekuninya), kompetensi pedagogik (penguasaan dosen pada berbagai macam pendekatan, metode, pengelolaan kelas, dan evaluasi pembelajaran yang sesuai dengan karakteristik materi dan perkembangan mahasiswa), kompetensi kepribadian (kesanggupan dosen untuk secara baik menampilkan dirinya sebagai teladan dan memperlihatkan antusiasme dan kecintaan terhadap profesinya), dan kompetensi sosial (kemampuan dosen untuk menghargai kemajemukan, aktif dalam berbagai kegiatan sosial, dan mampu bekerja sama dalam kelompok).

Di samping itu, dosen harus memiliki sertifikat pendidik yang diperoleh setelah lulus sertifikasi yang dilakukan oleh perguruan tinggi yang menyelenggarakan program pengadaan tenaga kependidikan pada perguruan tinggi yang ditetapkan oleh Pemerintah seperti disyaratkan dalam pasal 47 (1) Undang-undang Nomor 14 Tahun 2005 tentang Guru dan Dosen tersebut.

Sesuai dengan Undang-undang RI Nomor 14 Tahun 2005 tentang Guru dan Dosen, pasal 48, ayat (1), status dosen terdiri atas dua, yaitu dosen tetap dan dosen tidak tetap. Selanjutnya kedua status ini menjadi sebutan dalam klasifikasi dosen termasuk di IAIN Padangsidimpuan.

Dosen tetap adalah dosen yang terikat penuh waktu di IAIN Padangsidimpuan. Dosen tetap adalah Pegawai Negeri Sipil (PNS) yang 
diakui keberadaannya di IAIN Padangsidimpuan samapi batas waktu yang ditentukan. Sedangkan dosen tidak tetap adalah dosen yang terikat dalam hubungan kerja dengan IAIN Padangsidimpuan untuk jangka waktu tertentu. Dosen tidak tetap termasuk dosen luar biasa dan dosen tamu.

Dalam pasal 48 (2) undang-undang tersebut juga menyebutkan bahwa jenjang jabatan akademik dosen tetap terdiri atas asisten ahli, lektor, lektor kepala, dan profesor. Selanjutnya jabatan akademik profesor harus memiliki kualifikasi akademik doktor seperti disyaratkan dalam pasal 48 , ayat (3) undang-undang tersebut.

\section{Tugas Dosen}

Dosen adalah tenaga profesional pada jenjang pendidikan tinggi yang diangkat sesuai dengan peraturan perundang-undangan. Pengakuan kedudukan dosen sebagai tenaga profesional tersebut dibuktikan dengan sertifikat pendidik. Hal ini mengindikasikan bahwa dosen tersebut memiliki profesionalitas sesuai dengan kompetensi dan bidang keahlian keilmuannya di perguruan tinggi tersebut.

Tugas utama dosen adalah tugas pokok untuk melaksanakan tridharma perguruan tinggi yang meliputi pendidikan dan pengajaran, penelitian, dan pengabdian kepada masyarakakt. Sedangkan tugas penunjang adalah tugas tambahan dosen yang dilakukan di dalam maupun di luar tempat tugas dosen. Adapun penjelasan tentang tugas dosen, adalah:

1. Tugas dosen dalam bidang pendidikan dan pengajaran, adalah;

a. Menyelenggarakan pendidikan dan pengajaran sesuai dengan bidang keilmuannya masing-masing kepada mahasiswa sehingga memperoleh pengetahuan.

b. Membimbing mahasiswa untuk berpikir kritis dan analitis sehingga mampu dalam penulisan skripsi secara mandiri.

c. Membina mahasiswa dalam segi intelektual maupun mental.

2. Tugas dosen dalam bidang penelitian, adalah:

a. Melakukan penelitian secara mandiri dan kolektif dengan teman sejawat sehingga dapat dipublikasikan kepada masyarakat ilmiah. 

b. Menghasilkan karya ilmiah dalam mengembangkan ilmu pengetahuan.

3. Tugas dosen dalam bidang pengabdian kepada masyarakat, adalah:
a. Mengimplementasikan pengetahuannya dalam kegiatan pengabdian kepada masyarakat.
b. Melakukan pelayanan kepada masyarakat.

4. Tugas dosen dalam bidang penunjang tridharma perguruan tinggi, adalah:

a. Mengembangkan profesionalitasnya melalui partisipasi dan peran aktif dalam organisasi.

b. Mengaktualisasikan pengetahuannya dalam bekerja sama dalam tim dengan pihak lain dalam manajemen akademik untuk pencapaian tujuan institusi.

\section{Sertifikasi dan Kompetensi Dosen}

Sertifikasi adalah proses pemberian sertifikat pendidik untuk guru dan dosen. Sertifikat pendidik adalah bukti formal sebagai pengakuan yang diberikan kepada guru dan dosen sebagai tenaga profesional. ${ }^{5}$ Pelaksanaan sertifikasi dosen adalah respon terhadap Undang-undang RI Nomor 14 Tahun 2005 tentang Guru dan Dosen. Dalam pelaksanaannya, sertifikasi dosen PTAI mengacu pada regulasi, prosedur dan format nasional sertifikasi dosen Kementerian Pendidikan Nasional, baik dari segi instrumen, mekanisme, pemetaan prioritas dosen yang akan disertifikasi, uji portofolio, dan sebagainya, yang kemudian disesuaikan dengan standar dan format spesifik PTAI.

Sertifikasi dosen merupakan program yang bertujuan untuk meningkatkan kreatifitas dan kualitas kinerja dosen agar para dosen mampu mengaktualisasikan potensi diri secara lebih optimal sebagaimana tercermin dalam misi tridharma perguruan tinggi (pembelajaran, penelitian dan pengabdian) dalam rangka meningkatkan mutu pendidikan tinggi di

5 Undang-undang Republik Indonesia Nomor 14 Tahun 2005 tentang Guru dan Dosen, Bab I, Pasal 1, Ayat 11 dan 12 
Indonesia, dalam kaitan ini terutama di lingkungan Perguruan Tinggi Agama Islam (PTAI). 6

Pengakuan kedudukan dosen sebagai tenaga profesional dibuktikan dengan sertifikat pendidik. 7 Pengakuan ini ditujukan agar dosen benarbenar menjadi profesional dalam melaksanakan tugas pokok dan fungsinya sebagai tenaga pendidik, karena dosen adalah pendidik profesional dan ilmuwan dengan tugas utama mentransformasikan, mengembangkan, dan menyebarluaskan ilmu pengetahuan, teknologi, dan seni melalui pendidikan, penelitian, dan pengabdian kepada masyarakat. Profesional adalah pekerjaan atau kegiatan yang dilakukan oleh seseorang dan menjadi sumber penghasilan kehidupan yang memerlukan keahlian, kemahiran, atau kecakapan yang memenuhi standar mutu atau norma tertentu serta memerlukan pendidikan profesi. 8

Kedudukan dosen sebagai tenaga profesional berfungsi untuk meningkatkan martabat dan peran dosen sebagai agen pembelajaran, pengembang ilmu pengetahuan, teknologi, dan seni, serta pengabdi kepada masyarakat berfungsi untuk meningkatkan mutu pendidikan nasional. 9 Seorang dosen dapat memperoleh sertifikat pendidik, sebagai pengakuan terhadapnya, harus memenuhi kualifikasi akademik dan kompetensi tertentu. Kualifikasi akademik adalah ijazah jenjang pendidikan akademik yang harus dimiliki oleh guru atau dosen sesuai dengan jenis, jenjang, dan satuan pendidikan formal di tempat penugasan. Kompetensi adalah seperangkat pengetahuan, keterampilan, dan perilaku yang harus dimiliki, dihayati, dan dikuasai oleh guru atau dosen dalam melaksanakan tugas keprofesionalan. ${ }^{10}$

${ }^{6}$ Mohamamd Ali, "Kata Pengantar" dalam Muhammad Zain, dkk (Tim Penyusun), Pedoman Sertifikasi Pendidik untuk Dosen Perguruan Tinggi Agama Islam, Buku II: Penyusunan Portofolio (Jakarta: Direktorat Pendidikan Tinggi Islam Kementerian Agama RI, 2010), hlm. iii.

7 Undang-undang Republik Indonesia Nomor 14 Tahun 2005 tentang Guru dan Dosen, Bab II, Pasal 3, Ayat 2.

8 Undang-undang Republik Indonesia Nomor 14 Tahun 2005, Bab I, Pasal 1, Ayat 2, dan 4.

9 Undang-undang Republik Indonesia Nomor 14 Tahun 2005 Bab II, Pasal 5.

10 Undang-undang Republik Indonesia Nomor 14 Tahun 2005, Bab I, Pasal 1, Ayat 9 dan 10. 
Yang dimaksud dengan kompetensi pedagogik adalah kemampuan mengelola pembelajaran peserta didik. Yang dimaksud dengan kompetensi kepribadian adalah kemampuan kepribadian yang mantap, berakhlak mulia, arif, dan berwibawa serta menjadi teladan peserta didik. Yang dimaksud dengan kompetensi profesional adalah kemampuan penguasaan materi pelajaran secara luas dan mendalam. Yang dimaksud dengan kompetensi sosial adalah kemampuan untuk berkomunikasi dan berinteraksi secara efektif dan efisien dengan peserta didik, sesama tenaga pendidik, orangtua/wali peserta didik, dan masyarakat sekitar. ${ }^{11}$

Profesi dosen merupakan bidang pekerjaan khusus yang dilaksanakan berdasarkan prinsip sebagai berikut:

a. Memiliki bakat, minat, panggilan jiwa, dan idealisme;

b. Memiliki komitmen untuk meningkatkan mutu pendidikan, keimanan, ketakwaan, dan akhlak mulia;

c. Memiliki kualifikasi akademik dan latar belakang pendidikan sesuai dengan bidang tugas;

d. Mememiliki kompetensi yang diperlukan sesuai dengan bidang tugas;

e. Memiliki tanggung jawab atas pelaksanaan tugas keprofesionalan;

f. Memperoleh penghasilan yang ditentukan sesuai dengan prestasi kerja;

g. memiliki kesempatan untuk mengembangkan keprofesionalan secara berkelanjutan dengan belajar sepanjang hayat;

h. memiliki jaminan perlindungan hukum dalam melaksanakan tugas keprofesionalan;

i. memiliki organisasi profesi yang mempunyai kewenangan mengatur hal-hal yang berkaitan dengan tugas keprofesionalan guru. ${ }^{12}$

Sertifikat pendidik untuk dosen diberikan setelah memenuhi syarat sebagai berikut:

11 Lampiran Penjelasan atas Undang-undang Republik Indonesia Nomor 14, Pasal 10, Ayat 1.

12 Undang-undang Republik Indonesia Nomor 14 Tahun 2005, Bab III, Pasal, Ayat 1. 
a. Memiliki pengalaman kerja sebagai pendidik pada perguruan tinggi sekurang-kurangnya 2 (dua) tahun;

b. Memiliki jabatan akademik sekurang-kurangnya asisten ahli;

c. Lulus sertifikasi yang dilakukan oleh perguruan tinggi yang menyelenggarakan program pengadaan tenaga kependidikan pada perguruan tinggi yang ditetapkan oleh Pemerintah. ${ }^{13}$

Pemberdayaan profesi dosen diselenggarakan melalui pengembangan diri yang dilakukan secara demokratis, berkeadilan, tidak diskriminatif, dan berkelanjutan dengan menjunjung tinggi hak asasi manusia, nilai keagamaan, nilai kultural, kemajemukan bangsa, dan kode etik profesi. ${ }^{14}$ Oleh karena itu, dosen wajib memiliki kualifikasi akademik, kompetensi, sertifikat pendidik, sehat jasmani dan rohani, dan memenuhi kualifikasi lain yang dipersyaratkan satuan pendidikan tinggi tempat bertugas, serta memiliki kemampuan untuk mewujudkan tujuan pendidikan nasional. ${ }^{15}$

Untuk memenuhi tugasnya dosen dibebankan sejumlah tugas yang disebut Beban Kerja Dosen (BKD) mencakup kegiatan pokok yaitu merencanakan pembelajaran, melaksanakan proses pembelajaran, melakukan evaluasi pembelajaran, membimbing dan melatih, melakukan penelitian, melakukan tugas tambahan, serta melakukan pengabdian kepada masyarakat. Beban kerja tersebut sekurang- kurangnya sepadan dengan 12 (dua belas) satuan kredit semester dan sebanyak-banyaknya 16 (enam belas) satuan kredit semester. ${ }^{16}$

\section{Penyusunan Portofolio}

Sertifikasi pendidik untuk dosen dilakukan melalui uji kompetensi dalam bentuk portofolio untuk memperoleh sertifikat pendidik. Penilaian

13 Undang-undang Republik Indonesia Nomor 14 Tahun 2005, Bab V, Pasal 47.

14 Undang-undang Republik Indonesia Nomor 14 Tahun 2005, Bab III, Pasal 7, Ayat 2.

15 Undang-undang Republik Indonesia Nomor 14 Tahun 2005, Bab V, Pasal 45.

16 Undang-undang Republik Indonesia Nomor 14 Tahun 2005 tentang Guru dan Dosen, Bab V, Pasal 72. 
portofolio ini merupakan penilaian pengalaman akademik dan professional dengan menggunakan portofolio dosen untuk menentukan pengakuan atas kemampuan profesional dosen, dalam bentuk penilaian terhadap kumpulan dokumen yang mendeskripsikan kualifikasi akademik dan unjuk kerja tridharma perguruan tinggi; persepsi dari atasan, sejawat, mahasiswa dan diri sendiri tentang kepemilikan kompetensi pedagogik, profesional, sosial dan kepribadian; dan pernyataan diri tentang kontribusi dosen yang bersangkutan dalam pelaksanaan pengembangan tridharma perguruan tinggi. 17

Dengan kata lain, portofolio dosen disusun berdasarkan instrument: penilaian persepsional, penilaian deskripsi diri (penilaian personal); dan penilaian angka kredit (PAK). Penilaian persepsional meliputi penilaian dari mahasiswa, teman sejawat, atasan langsung dan dosen yang diusulkan. Penilaian ini dilakukan dengan memberi skor pada instrumen yang diberikan. Instrumen persepsional terdiri dari kelompok skor untuk kompetensi pedagogi, profesional, kepribadian, dan sosial.

Setiap butir instrumen diberi lima pilihan dengan kriteria sebagai berikut.

1 = sangat tidak baik/sangat rendah/tidak pernah

2 = tidak baik/rendah/jarang

3 = biasa/cukup/kadang-kadang

$4=$ baik/tinggi/sering

5 = sangat baik/sangat tinggi/selalu .

Kelulusan sertifikasi didasarkan pada:

a. Rerata skor komponen dan total instrumen penilaian persepsional yang meliputi penilaian dari: . mahasiswa, teman Sejawat, atasan langsung, dan dosen yang diusulkan.

b. Nilai akhir deskripsi diri, yang merupakan nilai kontribusi tridharma perguruan tinggi dari dosen.

c. Nilai konsistensi antara instrumen penilaian persepsional dan personal.

17 Peraturan Pemerintah Republik Indonesia Nomor 37 Tahun 2009 tentang Dosen, Pasal 4. 
d. Nilai Gabungan PAK dan nilai persepsional. ${ }^{18}$

Pelaksanaan kegiatan sertifikasi dosen tahun 2012 telah menggunakan sistem online. Kegiatan pengisian data, penyusunan portopolio, dan penilaian dilakukan melalui media internet.

\section{Beban Kerja Dosen}

a. Tugas Pendidikan dan Pengajaran

Tugas pendidikan dan pengajaran merupakan kegiatan yang wajib dilakukan oleh setiap dosen pada jenjang Strata Satu (S1). Beban Kerja yang wajib ditunaikan oleh dosen pada Pendidikan dan Pengajaran dengan bobot - bersama-sama dengan dharma penelitian dan pengembangan ilmu - sekurang-kurangnya 9 (sembilan) SKS setiap semester pada perguruan tinggi tempat bertugas.

Penghitungan SKS dalam beban kerja bidang Pendidikan dan Pengajaran setara dengan 50 (lima puluh) menit tatap muka di kelas, 60 (enam puluh) menit kegiatan mandiri, dan 60 (enam puluh) menit kegiatan terstruktur.

Adapun tugas bidang Pendidikan dan Pengajaran dapat dilakukan dosen dengan bentuk kegiatan sebagai berikut:

1) Melaksanakan perkuliahan/tutorial dan menguji;

2) Menyelenggarakan kegiatan pendidikan di laboratorium, praktik keguruan, praktik bengkel/studio/teknologi pengajaran;

3) Membimbing seminar mahasiswa;

4) Membimbing Kuliah Kerja Lapangan (KKL), Praktek Pengalaman Lapangan (PPL), Praktek Dakwah Lapangan (PDL), Klinis Hukum, Praktek Bank Mini, dan sejenisnya;

5) Membimbing tugas akhir penelitian mahasiswa termasuk membimbing pembuatan laporan hasil penelitian akhir;

6) Menguji pada ujian akhir (komprehensif dan munaqasyah);

7) Mengembangkan program perkuliahan;

8) Mengembangkan bahan pengajaran;

18 Muhammad Zain, dkk (Tim Penyusun), Pedoman Sertifikasi Pendidik untuk Dosen, hlm. 1. 
9) Membina kegiatan mahasiswa di bidang akademik dan kemahasiswaan;

10) Membimbing dosen yang lebih rendah jabatannya;

11) Melaksanakan kegiatan detasering, sabbatical leave, dan pencangkokan dosen.

Pelaksanaan Pendidikan dan Pengajaran dapat dijalankan dengan sistem perkuliahan biasa, system asistensi, system modul, dan team teaching.

b. Tugas Penelitian dan Pengembangan IImu

Tugas penelitian merupakan kegiatan yang wajib dilakukan oleh dosen, baik secara perorangan maupun berkelompok, dibiayai secara mandiri maupun lembaga. Dosen wajib menjalankan dharma penelitian - bersama-sama dengan dharma Pendidikan dan Pengajaran - dengan bobot sekurang-kurangnya 9 (sembilan) SKS setiap semester. Bobot dharma penelitian pada dosen sekurang-kurangnya 3 (tiga) SKS persemester.

Tugas Penelitian dan Pengembangan IImu dapat dilakukan dosen dengan bentuk kegiatan sebagai berikut:

1) Menghasilkan karya penelitian;

2) Menerjemahkan/menyadur buku ilmiah;

3) Mengedit/menyunting karya ilmiah;

4) Membuat rancangan, karya teknologi, dan karya seni;

5) Menyampaikan orasi ilmiah dan pembicara seminar.

c. Tugas Pengabdian kepada Masyarakat

Tugas pengabdian kepada masyarakat harus dilaksanakan oleh setiap dosen melalui kegiatan pengabdian kepada masyarakat yang dilaksanakan oleh Institut Agama Islam Negeri Padangsidimpuan atau melalui lembaga lain sebanyak-banyaknya setara dengan 3 (tiga) SKS dalam satu semester.

Tugas pengabdian dapat dilakukan dosen dengan bentuk kegiatan sebagai berikut: 
1) Melaksanakan pengembangan hasil pendidikan dan penelitian yang dapat dimanfaatkan oleh masyarakat;

2) Memberi latihan/penataran/penyuluhan/ceramah kepada masyarakat;

3) Memberi pelayanan secara langsung kepada masyarakat atau kegiatan lain yang menunjang pelaksanaan tugas umum pemerintah dan pembangunan;

4) Membuat/menulis karya pengabdian kepada masyarakat.

d. Tugas Penunjang Dosen

Tugas penunjang Tridharma Perguruan Tinggi dapat diperhitungkan sks-nya sebanyak-banyaknya sepadan dengan 3 (tiga) SKS setiap semester. Tugas tersebut dapat berupa sebagai berikut:

1) Menjadi penasehat akademik;

2) Menjadi anggota dalam suatu panitia/badan pada perguruan tinggi;

3) Menjadi anggota panitia/badan pada lembaga pemerintah;

4) Menjadi anggota organisasi profesi;

5) Mewakili perguruan tinggi/lembaga pemerintah duduk dalam panitia antar lembaga;

6) Menjadi anggota delegasi nasional dalam pertemuan internasional;

7) Berperan aktif dalam pertemuan ilmiah;

8) Mendapat tanda jasa/penghargaan;

9) Menulis buku pelajaran SLTA ke bawah;

10) Mempunyai prestasi di bidang olahraga/kesenian/sosial. ${ }^{19}$

\section{Evaluasi Beban Kerja Dosen}

Evaluasi Beban Kerja Dosen dibagi atas 4 bidang, yaitu bidang Pendidikan (PD), Penelitian (PL), Pengabdian kepada Masyarakat (PG),

19 Tim Penyususn Kementerian Agama RI, Pedoman Beban Kerja Dosen dan Evaluasi Pelaksanaan Tridharma Perguruan Tinggi di Lingkungan PTAl (Jakarta: Kementerian Agama RI, 2012). 
dan Pendukung/Penunjang (PK). Evaluasi Beban Kerja Dosen tersebut bertujuan untuk:

a. Meningkatkan profesionalisme dan pemenuhan dosen dalam melaksanakan beban tugas Tridharma Perguruan Tinggi;

b. Meningkatkan mutu proses dan hasil pelaksanaan beban tugas Tridharma Perguruan Tinggi;

c. Menilai akuntabilitas kinerja dosen di semua Fakultas dan program studi di lingkungan IAIN Padangsidimpuan;

d. Menciptakan suasana akademik yang kompetitif untuk menjamin kelancaran tugas utama dosen di lingkungan IAIN Padangsidimpuan;

e. Menjamin pembinaan, pengelolaan dan pengembangan profesi dan karier dosen; dan

f. Mempercepat terwujudnya tujuan Pendidikan Nasional. ${ }^{20}$

Adapun prosedur Evaluasi Beban Kerja Dosen dan Pelaksanaan Tridharma Perguruan Tinggi di IAIN Padangsidimpuan sebagai berikut:

a. Dosen membuat Laporan Beban Kerja Dosen (LBKD) pada akhir setiap semester dengan cara mengisi aplikasi BKD yang disediakan atau dapat juga men-download aplikasi terbaru dari www.serdosdiktis.net. LBKD ini memuat semua aktivitas Tridharma Perguruan Tinggi yang meliputi dharma Pendidikan dan Pengajaran, Penelitian, dan Pengabdian kepada Masyarakat, serta aktivitas penunjang lainnya dalam format laporan (format F1). LBKD disertai dengan semua bukti pendukungnya.

b. Dosen menyerahkan LBKD, dalam bentuk soft copy (1 CD) dan hard copy (rangkap 3), kepada Pusat Penjaminan Mutu Pendidikan (P2MP) IAIN Padangsidimpuan.

c. Pusat Penjaminan Mutu Pendidikan (P2MP) mendistribusikan LBKD (format F1) dan bukti pendukung tersebut kepada 2 (dua) asesor untuk menilai ketercapaian ekivalensi perhitungan SKS, dan memverifikasi kesesuain dokumen pendukung dengan aktivitas Tridharma Perguruan Tinggi yang telah dilakukan.

20 Buku Pedoman Beban Kerja Dosen dan Evaluasi Pelaksanaan Tridharma Perguruan Tinggi di Lingkungan Institut Agama Islam Negeri Padangsidimpuan 
d. Hasil penilaian asesor diserahkan kembali ke P2MP untuk dikompilasi.

e. Jika hasil dinyatakan LULUS/Memenuhi (M), maka P2MP menyerahkan dokumen hasil evaluasi ke Fakultas untuk disahkan.

f. Bukti pendukung laporan yang telah lolos dikembalikan kepada dosen yang bersangkutan untuk disimpan kembali dan dapat ditunjukkan apabila diperlukan.

g. Bagi dosen yang TIDAK LULUS/Tidak Memenuhi (T), maka P2MP mengembalikan berkas laporan F1 beserta bukti pendukungnya ke dosen yang bersangkutan. Jika terjadi selisih pendapat anatara asesor satu dengan asesor dua, maka Rektor IAIN dapat menunjuk asesor ketiga.

h. P2MP menyerahkan Hasil Penilaian Laporan Beban Kerja Dosen kepada Dekan Fakultas untuk mendapatkan pengesahan setelah dikompilasi. Dekan Fakultas bertanggung jawab dan berwenang untuk memverifikasi kebenaran laporan semua laporan kinerja dosen yang menjadi tanggung jawabnya.

i. Hasil kompilasi di tingkat Fakultas ini kemudian diserahkan kepada Rektor IAIN Padangsidimpuan untuk dibuat rekap di tingkat Institut. Rektor bertanggung jawab dan berwenang untuk memverifikasi kebenaran laporan yang telah disahkan oleh Dekan Fakultas.

j. Hasil kompilasi dan rekap LBKD di tingkat Institut diserahkan atau dikirim langsung kepada Direktorat Jenderal Pendidikan Islam c.q. Direktur Pendidikan Tinggi Islam setiap tahun oleh Rektor IAIN Padangsidimpuan. Laporan yang dikirim adalah: a. Rekap Institut (Lampiran 5) dalam bentuk hardfile; b. Softfile (CD) yang berisi: 1) Rekap tingkat Institut, 2) Rekap tingkat Fakultas, dan 3) Seluruh laporan kinerja dosen. Sedangkan hardfile dan bukti-bukti lainnya 1 (satu) berkas disimpan sebagai rekaman mutu pada Pusat Penjaminan Mutu Pendidikan untuk ditunjukkan sebagai bukti bila diperlukan, dan yang lainnya dikembalikan kepada dosen yang bersangkutan. ${ }^{21}$

21 Buku Pedoman Beban Kerja Dosen dan Evaluasi Pelaksanaan Tridharma Perguruan Tinggi di Lingkungan Institut Agama Islam Negeri Padangsidimpuan 
Prosedur pelaksanaan evaluasi kinerja dosen ini disajikan dalam Gambar yaitu:

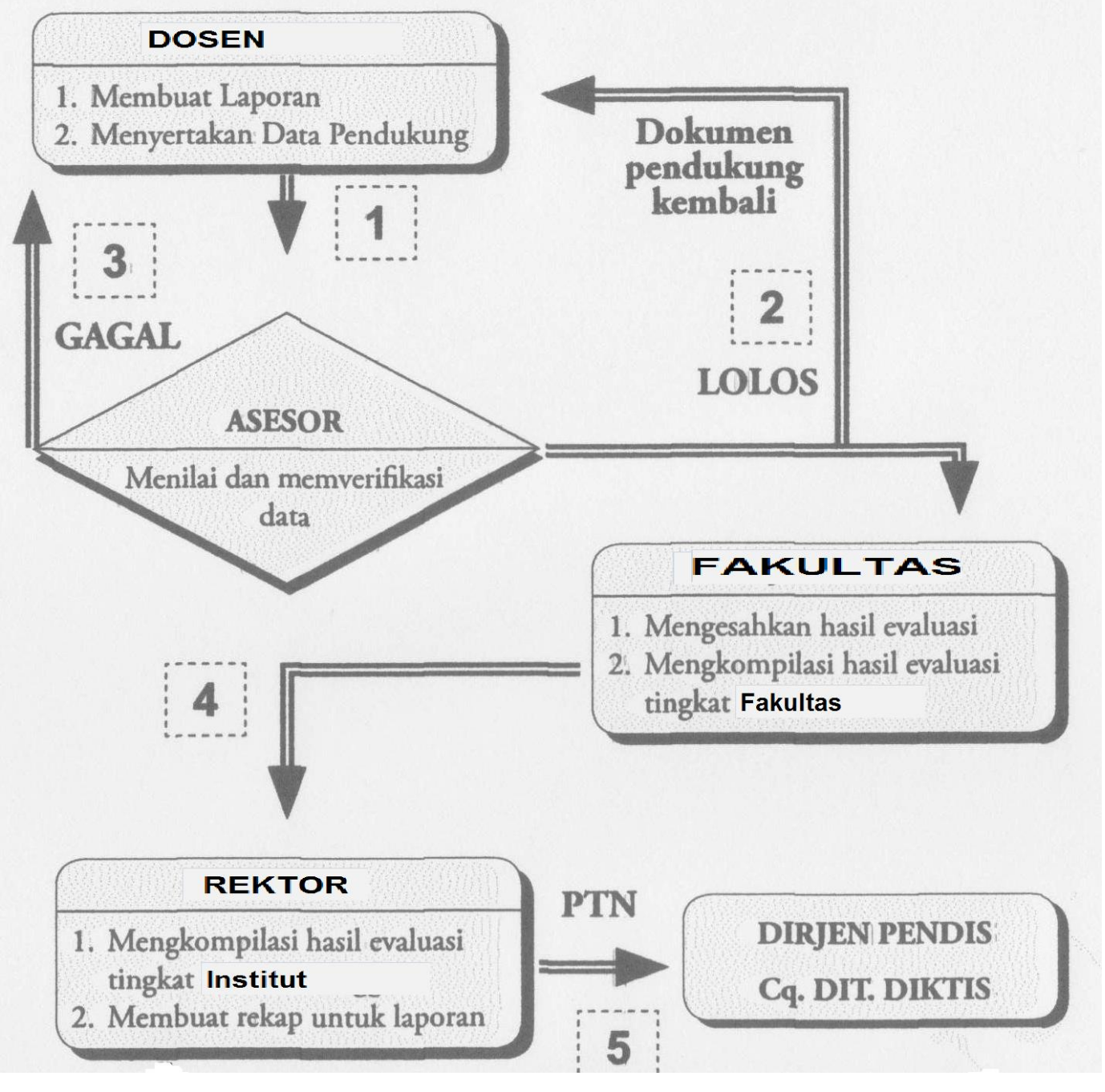

Gambar: Prosedur Evaluasi Kinerja Dosen

Beban Kerja Dosen ini sesuai dengan tuntutan Beban Kerja Dosen yang ditetapkan dalam pelaksanaan Tridharma Perguruan Tinggi, yaitu paling sedikit sepadan dengan 12 (dua belas) sks dan paling banyak 16 (enam belas) sks pada setiap semester dengan ketentuan sebagai berikut: 1. Beban Kerja yang wajib ditunaikan oleh dosen pada Pendidikan dan Pengajaran dengan bobot - bersama-sama dengan dharma penelitian 
dan pengembangan ilmu - sekurang-kurangnya 9 (sembilan) SKS setiap semester pada perguruan tinggi tempat bertugas.

2. Beban Kerja yang wajib dijalankan oleh Dosen pada dharma Penelitian - bersama-sama dengan dharma Pendidikan dan Pengajaran - dengan bobot sekurang-kurangnya 9 (sembilan) SKS setiap semester. Bobot dharma penelitian pada dosen sekurang-kurangnya 3 (tiga) SKS persemester.

3. Tugas pengabdian kepada masyarakat dan penunjang Tridharma Perguruan Tinggi dapat diperhitungkan sks-nya sebanyak-banyaknya sepadan dengan 3 (tiga) SKS setiap semester.

Dosen yang mendapat tugas tambahan sebagai pimpinan pada IAIN Padangsidimpuan wajib melaksanakan pendidikan paling sedikit sepadan dengan 12 SKS dikurangi nilai SKS tugas tambahan sebagai pimpinan pada IAIN Padangsidimpuan. ${ }^{22}$

Pelaksanaan sertifikasi dosen secara umum telah meningkatkan kinerja dosen. Hal ini, menurutnya, dapat dilihat dari peningkatan jumlah penulisan ilmiah dan buletin, namun dalam bidang pendidikan dan pengajaran masih terdapat dosen yang belum maksimal melaksanakan proses perkuliahan.

\section{Hambatan dalam pelaksanaan}

Hambatan yang dihadapi antara lain masih rendahnya pemahaman sebagian dosen terhadap tugas dan beban kerja yang harus dilaksanakannya, dan sebagian dosen masih rendah tingkat kesadaran untuk melaksanakan tugas Tridharma Perguruan Tingginya.

\section{Analisis Hasil Penelitian}

Dosen adalah salah satu komponen esensial dalam suatu sistem pendidikan di perguruan tinggi. Peran, tugas, dan tanggungjawab dosen sangat penting dalam mewujudkan tujuan pendidikan nasional, yaitu mencerdaskan kehidupan bangsa, meningkatkan kualitas manusia

22Buku Pedoman Beban Kerja Dosen dan Evaluasi Pelaksanaan Tridharma Perguruan Tinggi di Lingkungan Institut Agama Islam Negeri Padangsidimpuan 
Indonesia, yang meliputi kualitas iman/takwa, akhlak mulia, dan penguasaan ilmu pengetahuan, teknologi, dan seni, serta mewujudkan masyarakat Indonesia yang maju, adil, makmur, dan beradab. Untuk melaksanakan fungsi, peran, dan kedudukan yang sangat strategis tersebut, diperlukan dosen yang profesional.

Sebagaimana diamanatkan dalam Undang-undang Nomor 14 Tahun 2005 tentang Guru dan Dosen, dosen dinyatakan sebagai pendidik profesional dan ilmuwan dengan tugas utama mentransformasikan, mengembangkan, dan menyebarluaskan ilmu pengetahuan, teknologi, dan seni melalui pendidikan, penelitian, dan pengabdian kepada masyarakat (Bab 1 Pasal 1 ayat 2). Sementara itu, profesional dinyatakan sebagai pekerjaan atau kegiatan yang dilakukan oleh seseorang dan menjadi sumber penghasilan kehidupan yang memerlukan keahlian, kemahiran, atau kecakapan yang memenuhi standar mutu atau norma tertentu serta memerlukan pendidikan profesi.

Kompetensi tenaga pendidik, khususnya dosen, diartikan sebagai seperangkat pengetahuan, keterampilan dan perilaku yang harus dimiliki, dihayati, dikuasai dan diwujudkan oleh dosen dalam melaksanakan tugas profesionalnya. Kompetensi tersebut meliputi kompetensi paedagogik, kompetensi personal, kompetensi sosial dan kompetensi profesional.

Tugas utama dosen adalah melaksanakan Tridharma Perguruan Tinggi dengan beban kerja paling sedikit sepadan dengan 12 (dua belas) sks dan paling banyak 16 (enam belas) sks pada setiap semester sesuai dengan kualifikasi akademik. Sedangkan profesor atau guru besar adalah dosen dengan jabatan akademik tertinggi pada satuan pendidikan tinggi dan mempunyai tugas khusus menulis buku dan karya ilmiah serta menyebarluaskan gagasannya untuk mencerahkan masyarakat. Pelaksanaan tugas utama dosen ini perlu dievaluasi dan dilaporkan secara periodik sebagai bentuk akuntabilitas kinerja dosen kepada para pemangku kepentingan.

Kompetensi dosen menentukan kualitas pelaksanaan Tridharma Perguruan Tinggi sebagaimana yang ditunjukkan dalam kegiatan profesional dosen. Untuk menjamin pelaksanaan tugas dosen berjalan 
sesuai dengan kriteria yang ditetapkan dalam peraturan perundangundangan, maka perlu dievaluasi setiap periode waktu yang ditentukan.

Pelaksanaan sertifikasi dosen merupakan salah satu upaya untuk meningkatkan kinerja dosen dalam pelaksanaan Tridharma Perguruan Tinggi. Pelaksanaan sertifikasi ini di IAIN Padangsidimpuan telah memotifasi dosen untuk memenuhi beban kerjanya secara baik.

\section{Penutup}

Pelaksanaan sertifikasi dosen di Institut Agama Islam Negeri Padangsidimpuan telah berlangsung 4 (empat) angkatan, yaitu angkatan I berjumlah 29 (dua puluh sembilan) orang; angkatan II berjumlah 33 (tiga puluh tiga) orang; angkatan III berjumlah 19 (sembilan belas) orang; dan angkatan VI berjumlah 8 (delapan) orang, sehingga jumlah dosen yang sudah tersertifikasi seluruhnya berjumlah 89 (delapan puluh sembilan) orang dari total jumlah dosen 98 (sembilan puluh delapan) orang.

Pelaksanaan sertifikasi dosen secara umum telah berjalan efektif dan dapat meningkatkan kinerja dosen. Hal ini dapat dilihat dari peningkatan jumlah penulisan ilmiah dan buletin, namun dalam bidang pendidikan dan pengajaran masih terdapat dosen yang belum maksimal melaksanakan proses perkuliahan

Hambatan yang dihadapi antara lain masih rendahnya pemahaman sebagian dosen terhadap tugas dan beban kerja yang harus dilaksanakannya, dan sebagian dosen masih rendah tingkat kesadaran untuk melaksanakan tugas Tridharma Perguruan Tingginya

\section{Daftar Pustaka}

Abudin Nata, Pemikiran Para Tokoh Pendidikan Islam, Jakarta: Raja Grapindo Pursada, 2003.

Ali Imran, Pembinaan Kompetensi Guru di Indonesia, Jakarta: Pustaka Jaya, 1995.

Burhan Bungin, Analisis Data Kualitatif, Jakarta: Raja Grafindo Persada, 2003.

Depdiknas, "Program Pembangunan Nasional Bidang Pendidikan", Error! Hyperlink reference not valid.. [25 Mar 2005]. 
Gunawan Adi, Kamus Lengkap Inggris-Indonesia Indonesia-Inggris, Surabaya: Kartika, tth.

H.M. Arifin, Kapita Selekta Pendidikan, Jakarta: Bumi Aksara, 2003.

Hamalik, Oemar, Pendidikan Guru, Jakarta: PT.Bumi Aksara, 2003.

Mathew B. Miles dan A. Michael, Qualitative Data Analysis, London: Sage Publication, 1984.

Muhabbinsyah, Psikologi Belajar, Jakarta: Logos Wacana IImu, 2001.

Muhammad Zain, dkk (Tim Penyusun), Pedoman Sertifikasi Pendidik untuk Dosen Perguruan Tinggi Agama Islam, Buku II: Penyusunan Portofolio, Jakarta: Direktorat Pendidikan Tinggi Islam Kementerian Agama RI, 2010.

Muhtar dan Erna Widodo. Konstruksi ke Arah Penelitian Deskriptif. Yokyakarta: Avyrouz. 2000.

Pidarta Made, Landasan Kependidikan, Jakarta: Rineka Cipta, 2000.

Presiden RI, Undang-Undang Nomor 20 Tahun 2003 tentang Sistem Pendidikan Nasional, Jakarta: Eka Jaya 2003.

------, Undang-Undang Nomor 14 Tahun 2005 tentang Guru dan Dosen, Jakarta: Ditjen Manajemen Dikdasmen, 2005.

Ramayulis, IImu Pendidikan Islam, Jakarta: Kalam Mulia, 2008.

Robin dan Coulter, Manajemen (Edisi kedelapan), Jakarta: PT Indeks, 2007.

Sondang P Siagian, Filsafah Administrasi, Jakarta : CV Masaagung, , 1990.

Sudarwan Danim, Inovasi Pendidikan dalam Upaya Peningkatan Profesionalisme Tenaga Kependidikan, Bandung: Pustaka Setia, 2002.

Suharsimi Arikunto, Dasar-dasar Evaluasi Pendidikan, Jakarta: Bumi Aksara, 1997.

Tita Meirina Djuwita, "Analisis Teoritik tentang Pentingnya Sumber Daya Manusia bagi Pembangunan", Jakarta: Formasi. Jumal Kajian Manajemen Pendidikan, No.9, Tahun V, Maret 2004: 8-15. 